\title{
CONTROLLING PEPPER WHITE MOLD DISEASE USING SOME AGRICULTURAL PRACTICES
}

\author{
M. A. Awad, E. Z. Khalifa and M. E. Leila \\ Faculty of agricultural, Menoufia University, Egypt. \\ Received: Jun. 16, $2019 \quad$ Accepted: Jul. 7, 2019
}

\begin{abstract}
ABESTRACT: White mold disease of pepper that cause about Sclerotinia sclerotiorum, is considered one of the most important disease which infected pepper. The disease symptoms were beginning with dark-green, water-soaked lesions on stems and fruits. Lesions expand rapidly under most conditions, and the affected parts become a watery rotten mass covered by white fungal growth. After several days, the fungal growth on external plant surfaces plant forms a white. Which develops a black exterior and white to beige interior several days later moldy growth and black sclerotia are characteristic of this disease, that cause also to a very loose in the crop. Efficacy of application of some agricultural practices, i.e. plant density, breeding of seedlings, irrigation, fertigation and transplanting date on control of white mold disease that caused by Sclerotinia sclerotiorum was examined under greenhouse conditions during summer seasons (2016/2017) in Belco Egypt Co. Farm Sadat city, Menoufia governorae. Three distances between the transplants were investigated, in addition to, two methods were used in the breeding of pepper plants (Orngery RZ F1 hybrid), three differnt levels of irrigation, three levels of fertigation, plant density and three transplanting date were also studied.
\end{abstract}

Key words: white mold; pepper, Sclerotinia and Agricultural practicess control.

\section{INTRODUCTION}

Pepper plants (Capsicum annum L.) with their two types sweet and hot pepper, are belonging to Solanaceae family, considered one of the most important vegetable crops in Egypt and most of the world wide. Pepper fruits have a wide variety shapes, sizes, colors and different degrees of pungency, based on the type of pepper species and the manner in which they are prepared and used (Babu, et al., 2002).

Pepper is characterized by its high nutritional value than tomatoes and potatoes crops, especially vitamin $C$ that human body needs especially in winter to prevent diseases like flu and common cold. As will as, its importance as food and spices, the capsacine substance extracts from hot pepper, which used for caring of some human diseases like bone aches resulting from rheumatoid, and fluoride substance which protect from teeth decay.
According to the yearly report of Ministry of Agriculture, Economic Statistics Department in 2016 (Nili and Summer vegetable crops), the total cultivated area of pepper in Egypt reached more than 27354 feddan, which yielded 195111 tons during Nili season while the total cultivated area of pepper during summer season 2016 reached to 97223 feddan which yielded 614273 tons.

In Egypt, pepper fruits are considered one of the most important fruit crops because of the high nutritive value, It is an important export crop because of its high quality which is desirable in the world market. Pepper plants are attacked by many pathogens, like fungi, bacteria, and viruses.

This investigation aimed to study the effect of some agricultural practices like, transplanting date, plant density, breeding, irrigation and fertigation on controlling the white mold disease of 
pepper plants, and minimizing use of chemical control and fungicides pollutions.

\section{MATERIALS AND METHODS}

The sore parts of affected plants by $S$. sclerotiorum and sclerotia bodes it considered one the most important infection sources with the white mold disease of pepper at the next season.

Under the Egyptian conditions at ElSadat City in Belca Egypt Co. Farm these experiments were applied.

These experiments were carried out at 2016 and 2017 seasons. Seedlings of Orangary RZ, the highly susceptible cultivar were transplanted in these studies. The experiments were done to study the effect of breeding seedlings, transplanting dates, irrigation, plant densities and effect of ( $N, P, K, C a, M g$, and $S$ ) levels of fertilization on white rot disease incidence.

\section{*Agricultural practices used in controlling pepper white mold disease :}

1. Transplanting date:

These experiments were done to make a limitation around the reliable time of transplanting to avoid disease attack. Three dates of transplanting i.e. $10^{\text {th }}$ of March , 20 th of July, and $20^{\text {th }}$ of November. The three dates of transplanting were distributed in a completely randomized block design with five replicates the plot size was $175 \mathrm{~m}^{2}$. Data of the disease incidence, disease severity and yield production wer recorded. The quantities of added fertilizers wer divided into four equal doses. The $1^{\text {st }}$ dose was applied after 15 days post transplanting, the $2^{\text {nd }}$ at the flowering stage, the $3^{\text {rd }}$ at the fruiting set and development fruits and the $4^{\text {th }}$ dose at harvest time.

\section{Plant density:}

These experiments were carried out at 2016 growing season. Seedlings of

$\begin{array}{lcr}\text { Orangery RZ } & \text { F1 hybrid; the highly } \\ \text { susceptible } & \text { pepper hybrid were } \\ \text { transplanted } & \text { under } & \text { greenhouse }\end{array}$

conditions.

Three distances between the transplants were applied $(20,30$ and 45 $\mathrm{cm}^{2}$ ). These three distances were distributed in completely randomized block design with five replicates. Plot size $175 \mathrm{~m}^{2}$. Data of disease incidence, disease severity, sclertia bodies and yield were recorded as mentioned before.

\section{Breeding of seedlings:}

In this experiment two methods were used in breeding of cultivated Orangery RZ F1 hybrid pepper seedlings: the first method is to raise the pepper seedlings on two branches (Dutch method) and the second is to raise the seedlings on three branches (Spanish method).

\section{Irrigation:}

Pepper crops are considered one of the most sensitive vegetable crops for irrigation. Pepper plants need large amounts of water, particularly in flowering and fruit holding, this is one of the most critical stages of growth in which are more susceptible to white mold disease, but to plant stress. The effect of different irrigation rates on severity of white mold disease was studied by flowering three different rates of irrigation over the stage of plant growth as shown in Table (1).

\section{Fertigation:}

The effect of different of fertilization on white mold disease incidence and the yield of pepper under natural infection were determined.

The experiments were carried out in split plot design with five replicates for each particular treatment, used levels of fertilizers during one growing season (Table 2). Plot area was $175 \mathrm{~m}^{2}$. Data of disease incidence and yield recorded as mentioned before. 
Source of different tested nutietional elements:

In this respecte, ammonium nitrate was used as $\mathbf{N}$ source, sulphate was used as Mg source, Potassium sulphate was used as $\mathrm{K}$ source, calcium nitrate was used as Ca source, Phosphoric acid was used as $P$ source, and sulphur acid was used as $S$ source.

\section{Results:}

(1) Transplanting date:

Data in Table (3) indicated that transplanting date of pepper affect on the response of highly susceptible cultivar "Orangery RZ F1 hybrid" to white mold infection. Results indicate to clear significant differences in white mold disease severity and disease incidence between the earliest transplanting $10^{\text {th }}$ March and each one of the other two transplanting dates i.e., $20^{\text {th }}$ July and $20^{\text {th }}$ November during the two growing seasons2016 and 2017. The highest disease incidence and disease severity of infection were recorded with the latest transplanting date, while transplanting at $10^{\text {th }}$ March was in reducing pepper white mold infection.

Also, disease incidence, and disease severity pepper white mold of infection in addition to fruit yield of pepper were differed according to the transplanting date. In this respect, the least values of DI, DS and fruit yield were recorded at transplanting date of $20^{\text {th }}$ July transplanting date, while the highest DI, DS of infection and lowest quantities of pepper fruit yield was recorded with the latest date of transplanting $\left(20^{\text {th }}\right.$ November).

$(2,3)$. Breeding method and distance planting

This experiment was applied by following three methods of breeding seedlings (Douch method, Spanish method and without breeding) planted at different distances $(20,30$ and $45 \mathrm{~cm})$.

Data in Table (4) indicated that during 2016 season, the douche method at $20 \mathrm{~cm}$ between seedlings recorded the lowest disease incidence, disease severity, sclerotia bodies and yield $(14.5 \%, 5.73 \%$, $5.4 \mathrm{~s} / \mathrm{p}$ and $4.28 \mathrm{~kg} / \mathrm{m}^{2}$, respectively), followed by Spanish method $(28.29 \%$, $11.95 \%, \quad 8.4 \mathrm{~s} / \mathrm{p}$ and $3.43 \mathrm{~kg} / \mathrm{m}^{2}$, respectively). In addition to increase of without breeding recorded the highest disease incidence, disease severity, sclerotia bodies and yield $(54.98 \%$, $23.99 \%, 11.2 \mathrm{~s} / \mathrm{p}$ and $3.69 \mathrm{~kg} / \mathrm{m}^{2}$ ). On the other hand, in case of planting the seedlings at a distance at a distance of $\mathbf{3 0}$ $\mathrm{cm}^{2}$. The Douch breeding method recorded the lowest disease incidence, disease severity, sclerotia bodies and yield $\left(5.0 \%, 1.5 \%, 0.0 \mathrm{~s} / \mathrm{p}\right.$ and $7.0 \mathrm{~kg} / \mathrm{m}^{2}$, respectively), in case of without breeding at $30 \mathrm{~cm}$ between seedlings, recorded the highest disease incidence, disease severity, slcerotia bodies and the yield $\left(38.69 \%, 20.58 \%, 8.4 \mathrm{~s} / \mathrm{p}\right.$ and $3.96 \mathrm{~kg} / \mathrm{m}^{2}$, respectively).

Table (1). The used levels of irrigation water (L/m) during one season.

\begin{tabular}{||l|c|c|c|c|c||}
\hline \multirow{2}{*}{\multicolumn{1}{|c|}{ Growth stage }} & \multicolumn{2}{|c|}{$\begin{array}{c}\text { Quantity of irrigation water } \\
\text { (L/m2)* }\end{array}$} & $\begin{array}{c}\text { No. of } \\
\text { irrigation } \\
\text { time/day }\end{array}$ & $\begin{array}{c}\text { Total } \\
\text { days }\end{array}$ \\
\cline { 2 - 6 } & Level 1 & Level 2 & Level 3 & \\
\hline Establishment stage & 0.5 & 0.5 & 0.5 & 1 & 5.0 \\
\hline Tilibeganining of fruit set stage & 0.7 & 1.0 & 1.5 & 2 & 42.0 \\
\hline Fruit set and development fruits stag & 1.0 & 1.5 & 2.0 & 2 & 43.0 \\
\hline Harvest stage & 1.5 & 2.0 & 3.0 & 2 & 180.0 \\
\hline * (liter/ meter2)
\end{tabular}




\begin{tabular}{|c|c|c|c|c|c|c|}
\hline \multicolumn{2}{|c|}{ 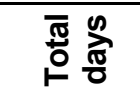 } & n & F & भ & $\stackrel{\infty}{\stackrel{\infty}{\circ}}$ & $\stackrel{\text { N }}{\text { N }}$ \\
\hline & \multirow{3}{*}{$\boldsymbol{\omega}$} & \&̊․ㅇ & 옹 & \&̊․ㅇ & 옹 & $R$ \\
\hline & & $\begin{array}{l}\text { Oे } \\
0\end{array}$ & $\begin{array}{l}\text { Oे } \\
0\end{array}$ & $\begin{array}{l}\text { Oे } \\
0\end{array}$ & ষ্ণ & 8 \\
\hline & & 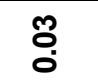 & 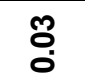 & \%̊ํㅇ & ஜ̊ & 오 \\
\hline & \multirow{3}{*}{$\sum^{\circ}$} & 今. & $\stackrel{\Upsilon}{0}$ & $\stackrel{1}{0}$ & $\frac{1}{0}$ & ৪ \\
\hline & & $\begin{array}{l}10 \\
8 \\
0\end{array}$ & $\delta_{0}$ & $\frac{10}{0}$ & $\frac{10}{0}$ & $R$ \\
\hline & & ஜ̊ & : & $\stackrel{\text { ㄱ}}{0}$ & $\stackrel{N}{\circ}$ & 8 \\
\hline \multirow{12}{*}{ 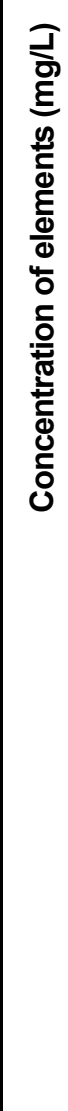 } & \multirow{3}{*}{ త } & $\stackrel{0}{0}$ & $\stackrel{0}{0}$ & : & : & ָㅗ \\
\hline & & ㅇ. & ㅇ. & O̊ & ষ্ণ & $\stackrel{ }{ }$ \\
\hline & & ㅇ. & O̊ & ণু & ণু & $\mathscr{\circ}$ \\
\hline & \multirow{3}{*}{ צ } & $\frac{N}{0}$ & $\frac{N}{0}$ & $\frac{ \pm}{0}$ & $\frac{\pi}{0}$ & 온 \\
\hline & & $\overline{0}$ & $\overline{0}$ & $\stackrel{\sim}{\circ}$ & $\frac{\mathfrak{T}}{0}$ & ని \\
\hline & & :̊․ㅇ & $\stackrel{\infty}{\circ}$ & $\overline{0}$ & $\overline{0}$ & 옴 \\
\hline & \multirow{3}{*}{ a } & $\stackrel{1}{0}$ & 농 & 농 & 농 & வ \\
\hline & & $\check{0}$ & $\begin{array}{l}\text { L } \\
\text { \& }\end{array}$ & $\begin{array}{l}\text { fo } \\
\text { O }\end{array}$ & 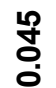 & ৪ \\
\hline & & $\stackrel{\infty}{0}$ & $\begin{array}{l}\text { 웅 } \\
\text { 잉 }\end{array}$ & 웅 & 웅 & \& \\
\hline & \multirow{3}{*}{$z$} & $\stackrel{\text { T. }}{0}$ & $\stackrel{\text { T. }}{0}$ & $\frac{ \pm}{0}$ & $\frac{\dot{T}}{0}$ & 워 \\
\hline & & $\overline{0}$ & б. & $\frac{\mathfrak{T}}{0}$ & $\frac{N}{0}$ & స్సి \\
\hline & & $\begin{array}{l}\infty \\
0 \\
0\end{array}$ & $\begin{array}{l}\infty \\
0 \\
0\end{array}$ & $\overline{0}$ & $\overline{0}$ & 움 \\
\hline \multicolumn{2}{|c|}{ 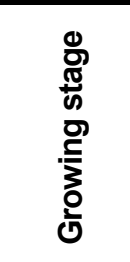 } & 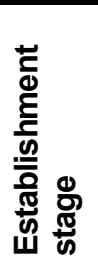 & 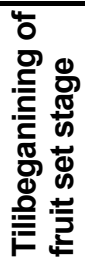 & 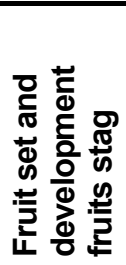 & 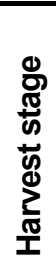 & 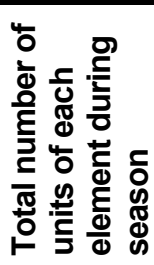 \\
\hline
\end{tabular}


Controlling pepper white mold disease using some agricultural practices

Table (3). Effect of transplanting date on white mold infection and fruit yield of pepper "Orangery RZ F1 hybrid" during 2016 and 2017 growing seasons.

\begin{tabular}{|c|c|c|c|c|c|c|c|c||}
\hline \multirow{2}{*}{ Transplanting date } & \multicolumn{4}{|c|}{2016 season } & \multicolumn{4}{c|}{2017 season } \\
\cline { 2 - 9 } & D.I.\% & D.S.\% & S.N. & Yield & D.I.\% & D.S.\% & S.N. & Y/m \\
\hline $10^{\text {th }}$ March & 15.71 & 7.33 & 2.0 & 5.0 & 17.93 & 9.21 & 3.0 & 5.2 \\
\hline $20^{\text {th }}$ July & 17.90 & 9.66 & 0.0 & 7.23 & 15.33 & 7.44 & 0.0 & 7.3 \\
\hline $20^{\text {th }}$ November & 22.0 & 15.0 & 3.0 & 3.61 & 24.66 & 13.22 & 5.0 & 4.10 \\
\hline
\end{tabular}

\begin{tabular}{||c|c|c|c|c|c|c|c|c|}
\hline LSD at 5\% & 4.14 & 4.87 & 0.26 & 0.84 & 4.36 & 4.72 & 0.41 & 0.89 \\
\hline
\end{tabular}

D.I. disease incidence D.S. disease severity

S.N./P. Sclerotia bodies number/plant

Y/M2 Yield/meter2

Table (4). Effect of different level of irrigation on white mold disease on pepper.

\begin{tabular}{|c|c|c|c|c|c|c|c|c|c|c|c|}
\hline \multirow{2}{*}{$\begin{array}{l}\text { Different } \\
\text { level of } \\
\text { irritation }\end{array}$} & \multicolumn{5}{|c|}{ Sandy soil } & \multicolumn{5}{|c|}{ Clay soil } & \multirow{2}{*}{ Control } \\
\hline & $y / m$ & P/L & s.n/p & DI & DS & $y / m$ & P/L & s.n/p & DI & DS & \\
\hline \multirow[b]{2}{*}{ Level 1} & \multicolumn{11}{|c|}{2016 season } \\
\hline & $4.8^{\mathrm{a}}$ & $131.66^{\mathrm{a}}$ & $6.33^{a}$ & $61.67^{a}$ & $41.67^{a}$ & $5.67^{\mathrm{a}}$ & $198.33^{\mathrm{a}}$ & $0.67^{\mathrm{a}}$ & $41.67^{a}$ & $21.67^{c}$ & 0.0 \\
\hline Level 2 & $7.4^{\mathrm{b}}$ & $210.0^{\mathrm{a}}$ & $0.67^{b}$ & $33.33^{b}$ & $25.0^{b}$ & $4.67^{\mathrm{a}}$ & $200.0^{\mathrm{b}}$ & $10.33^{b}$ & $6.67^{b}$ & $43.33^{b}$ & 0.0 \\
\hline \multirow[t]{2}{*}{ Level 3} & $3.8^{\mathrm{b}}$ & $213.3^{b}$ & $12.0^{c}$ & $83.33^{c}$ & $75.0^{c}$ & $2.67^{b}$ & $220.0^{\mathrm{b}}$ & $17.0^{c}$ & $96.67^{c}$ & $81.67^{a}$ & 0.0 \\
\hline & \multicolumn{11}{|c|}{2017 season } \\
\hline Level 1 & $4.67^{\mathrm{b}}$ & $133.33^{b}$ & 6.67 & $63.33^{b}$ & $45.0^{\mathrm{a}}$ & $5.9^{b}$ & $198.33^{c}$ & $2.0^{c}$ & $43.33^{a}$ & $23.33^{c}$ & 0.0 \\
\hline Level 2 & $7.73^{a}$ & $216.67^{\mathrm{a}}$ & 0.0 & $28.33^{c}$ & $18.33^{b}$ & $4.67^{b}$ & $203.33^{b}$ & $11.67^{\mathrm{b}}$ & $63.33^{b}$ & $43.33^{b}$ & 0.0 \\
\hline Level 3 & $3.16^{c}$ & $250.0^{a}$ & 14.0 & $86.67^{a}$ & $78.33^{c}$ & $2.67^{a}$ & $220.0^{a}$ & $17.0^{\mathrm{a}}$ & $96.67^{c}$ & $81.67^{a}$ & 0.0 \\
\hline
\end{tabular}

\begin{tabular}{||c|c|c|c|c|c|c|c|c|c|c|c||}
\hline $\begin{array}{c}\text { LSD at 5\% } \\
2016\end{array}$ & 1.12 & 22.83 & 3.4 & 8.16 & 8.80 & 1.15 & 14.5 & 2.75 & 8.16 & 17.30 & - \\
\hline $\begin{array}{c}\text { LSD at } 5 \% \\
2017\end{array}$ & 0.71 & 72.65 & 4.21 & 11.53 & 13.73 & 1.02 & 15.97 & 4.66 & 9.99 & 18.24 & - \\
\hline
\end{tabular}

D.I. disease incidence D.S. disease severity

S.N./P. Sclerotia bodies number/plant

Y/M2 Yield/meter2

$P / L \quad$ plant length

Spanish breeding method recorded the lowest disease incidence, disease severity, sclerotia bodies and the yield in case of planting the seedlings at $45 \mathrm{~cm}$ $\left(4.33 \%, 1.83 \%, 0.0 \mathrm{~s} / \mathrm{p}\right.$ and $\left.6.92 \mathrm{~kg} / \mathrm{m}^{2}\right)$. With Douche breeding methods it recorded $6.33 \%, 2.63 \%, 0.0 \mathrm{~s} / \mathrm{p}$ and 4.76 $\mathrm{kg} / \mathrm{m}^{2}$, respectively. 
Data in Table (5) showed that during 2017 season, Douche breeding methods, it was the best breeding methods in planting seedlings at a distance of $20 \mathrm{~cm}$ where recorded the lowest disease incidence and disease severity compared with Spanish breeding methods and in case of without breeding was also the best in planting seedlings at a distance of $30 \mathrm{~cm}$, where it recorded the lowest disease incidence and disease severity. But in case of planting seedlings at a distance of $45 \mathrm{~cm}$ was the Spanish breeding method is the best breeding methods used in the cultivation of seedlings, where it recorded the lowest disease incidence, disease severity, sclerotia bodies and the yield $(4.0 \%$, $1.83 \%, \quad 0.0 \mathrm{~s} / \mathrm{p}$ and $6.98 \mathrm{~kg} / \mathrm{m}^{2}$, respectively).

\section{(4). Irrigation}

Data in Table (5) showed that three levels of irrigation were carried out to determine the effect of the amount of irrigation water on the incidence of white mold disease on the orangery pepper and cultured in different soil types (sand soil and clay soil) during the 2016 and 2017 growth seasons. The case of planting seedlings in clay soil, the best amount of irrigation used was the first level compared to other irrigation levels, it recorded the lowest disease incidence, the best plant growth rate and the highest yield per square meter. But in case of planting seedlings in sandy soil, the best amount of irrigation used was the second level compared to other irrigation levels, It recorded the lowest disease incidence, disease severity, the best plant growth rate and the best of amount of yield.

Table (5). Effect of breeding method and distance planting on white mold disease of pepper (Orangary RZ variety) by aggressive isolate No. 7 of Sclerotinia sclerotiorum under greenhouse condition.

\begin{tabular}{|c|c|c|c|c|c|c|c|c|c|c|c|c|c|}
\hline \multirow{3}{*}{$\begin{array}{l}\text { Breeding } \\
\text { method }\end{array}$} & \multicolumn{12}{|c|}{ Distance planting (cm) } & \multirow{3}{*}{ Control } \\
\hline & \multicolumn{4}{|c|}{20} & \multicolumn{4}{|c|}{30} & \multicolumn{4}{|c|}{45} & \\
\hline & $\begin{array}{c}\text { Yield } / \\
\mathbf{m}\end{array}$ & $\mathrm{Sn} / \mathrm{p}$ & DI & DS & $\begin{array}{c}\text { Yield/ } \\
\text { m }\end{array}$ & $\mathrm{Sn} / \mathrm{p}$ & DI & DS & $\begin{array}{c}\text { Yield } / \\
\text { m }\end{array}$ & $\mathrm{Sn} / \mathrm{p}$ & DI & DS & \\
\hline & \multicolumn{13}{|c|}{2016 season } \\
\hline $\begin{array}{l}\text { Douche } \\
\text { method }\end{array}$ & $4.28^{a}$ & $5.4^{\mathrm{b}}$ & $14.5^{\mathrm{c}}$ & $5.73^{b}$ & $7.0^{\mathrm{a}}$ & $0.0^{b}$ & $5.0^{c}$ & $1.5^{\mathrm{c}}$ & $4.76^{b}$ & $0.0^{\mathrm{b}}$ & $6.33^{b}$ & $2.63^{b}$ & 0.0 \\
\hline $\begin{array}{l}\text { Spanish } \\
\text { method }\end{array}$ & $3.43^{b}$ & $8.4^{\mathrm{ab}}$ & $28.29^{b}$ & $11.95^{b}$ & $5.88^{b}$ & $2.6^{\mathrm{b}}$ & $16.2^{\mathrm{b}}$ & $9.99^{b}$ & $6.92^{\mathrm{a}}$ & $0.0^{\mathrm{b}}$ & $4.33^{b}$ & $1.83^{b}$ & 0.0 \\
\hline $\begin{array}{l}\text { Without } \\
\text { breeding }\end{array}$ & $3.69^{\mathrm{ab}}$ & $11.2^{\mathrm{a}}$ & $54.98^{\mathrm{a}}$ & $23.99^{a}$ & $3.96^{\mathrm{c}}$ & $8.4^{\mathrm{a}}$ & $38.69^{a}$ & $20.58^{a}$ & $4.34^{b}$ & $7.8^{a}$ & $24.2^{\mathrm{a}}$ & $11.25^{a}$ & 0.0 \\
\hline \multirow[b]{2}{*}{$\begin{array}{l}\text { Douche } \\
\text { method }\end{array}$} & \multicolumn{13}{|c|}{2017 season } \\
\hline & $4.2^{\mathrm{a}}$ & $5.0^{\mathrm{b}}$ & $15.82^{c}$ & $6.78^{b}$ & $7.26^{\mathrm{a}}$ & $0.0^{c}$ & $4.33^{c}$ & $1.5^{\mathrm{c}}$ & $4.76^{b}$ & $0.0^{\mathrm{b}}$ & $6.33^{b}$ & $2.63^{b}$ & 0.0 \\
\hline $\begin{array}{l}\text { Spanish } \\
\text { method }\end{array}$ & $3.13^{b}$ & $8.4^{\mathrm{ab}}$ & $32.97^{b}$ & $13.98^{b}$ & $5.8^{b}$ & $3.2^{\mathrm{b}}$ & $16.63^{b}$ & $10.0^{b}$ & $6.98^{\mathrm{a}}$ & $0.0^{\mathrm{b}}$ & $4.0^{b}$ & $1.83^{b}$ & 0.0 \\
\hline $\begin{array}{l}\text { Without } \\
\text { breeding }\end{array}$ & $3.79^{\mathrm{ab}}$ & $11.2^{\mathrm{a}}$ & $55.32^{\mathrm{a}}$ & $24.24^{a}$ & $4.44^{c}$ & $8.4^{a}$ & $39.38^{\mathrm{a}}$ & $20.58^{a}$ & $4.54^{b}$ & $7.8^{\mathrm{a}}$ & $22.98^{a}$ & $11.25^{a}$ & 0.0 \\
\hline
\end{tabular}

\begin{tabular}{|l|c|c|c|c|c|c|c|c|c|c|c|c|c||}
\hline $\begin{array}{c}\text { LSD at 5\% } \\
2016\end{array}$ & 0.75 & 4.52 & 13.16 & 8.34 & 0.23 & 3.14 & 9.25 & 3.81 & 0.44 & 1.53 & 10.26 & 6.44 & - \\
\hline $\begin{array}{c}\text { LSD at } 5 \% \\
2017\end{array}$ & 0.77 & 3.60 & 12.72 & 9.53 & 0.75 & 3.03 & 8.38 & 3.80 & 0.47 & 1.53 & 9.63 & 6.44 & - \\
\hline
\end{tabular}
D.I. disease incidence
S.N./P. Sclerotia bodies number /plant disease severity
Y/M2 Yie plant length




\section{(5). Fertigation}

Data in Table (6) showed that over the course of the 2016 and 2017 seasons the effect of three different levels of fertilization on white mold disease. During 2016 season, the level 2 of fertilizer recorded the lowest disease incidence, $3.45 \mathrm{~s} / \mathrm{p}$ and $6.72 \mathrm{~kg} / \mathrm{m}^{2}$, respectively), followed by level 3 of fertilization $(47.86 \%$, $24.72 \%, \quad 4.4 \mathrm{~s} / \mathrm{p}$ and $4.87 \mathrm{~kg} / \mathrm{m}^{2}$, respectively).

During the 2017 season, the level 2 of fertilization was more effective on Sclerotinia sclerotiorum and recorded the lowest disease incidence, disease severity, sclerotia bodies and yield $\left(36.4 \%, 13.47 \%, 3.13 \mathrm{~s} / \mathrm{p}\right.$ and $6.68 \mathrm{~kg} / \mathrm{m}^{2}$, respectively). On the other hand the level 3 of fertilization recorded the highest disease incidence, disease severity, sclerotia bodies and yield $(47.86 \%$, $24.59 \%, 4.64 \mathrm{~s} / \mathrm{p}$ and $4.72 \mathrm{~kg} / \mathrm{m}^{2}$, respectively).

\section{DISCUSSION}

Concerning to the effect of breeding and plant density on the disease incidence, disease severity of infection and yield production, data indicate that the lowest disease incidence and disease severity of infection when cultivating plants at a distance of $30 \mathrm{~cm}$ and follow the Dutch breeding as well as when planting plants at a distance of $45 \mathrm{~cm}$ and follow Spanish method of breeding. These results were relatively in harmony with Cother, E. J. (2000), Elad, Y. (2000), Vieire, R. F. et al. (2003), Ma Yan; et al. (2006), Wang Dong Sheng (2013) and Derbyshire, M. (2017).

Three levels of irrigation were used in two types of soil during 2015 growing season to determine the effect of the quantity of irrigation water on the disease incidence of white rot of pepper. The highest yield production and lowest disease incidence in case of sandy soil were $\left(0.5+0.7+10+1.5 \mathrm{~L} / \mathrm{m}^{2}\right)$. Nearly the same observations were also noticed at 2016 growing season. These results were relatively in harmony with Yusuf, Y.; Sally, M. (2004).

Table (6). Effect of different rates of nutrients on white rot disease in pepper under artificial inoculation with isolate No. 7 of Sclerotinia sclerotiorum (2016 and 2017 seasons).

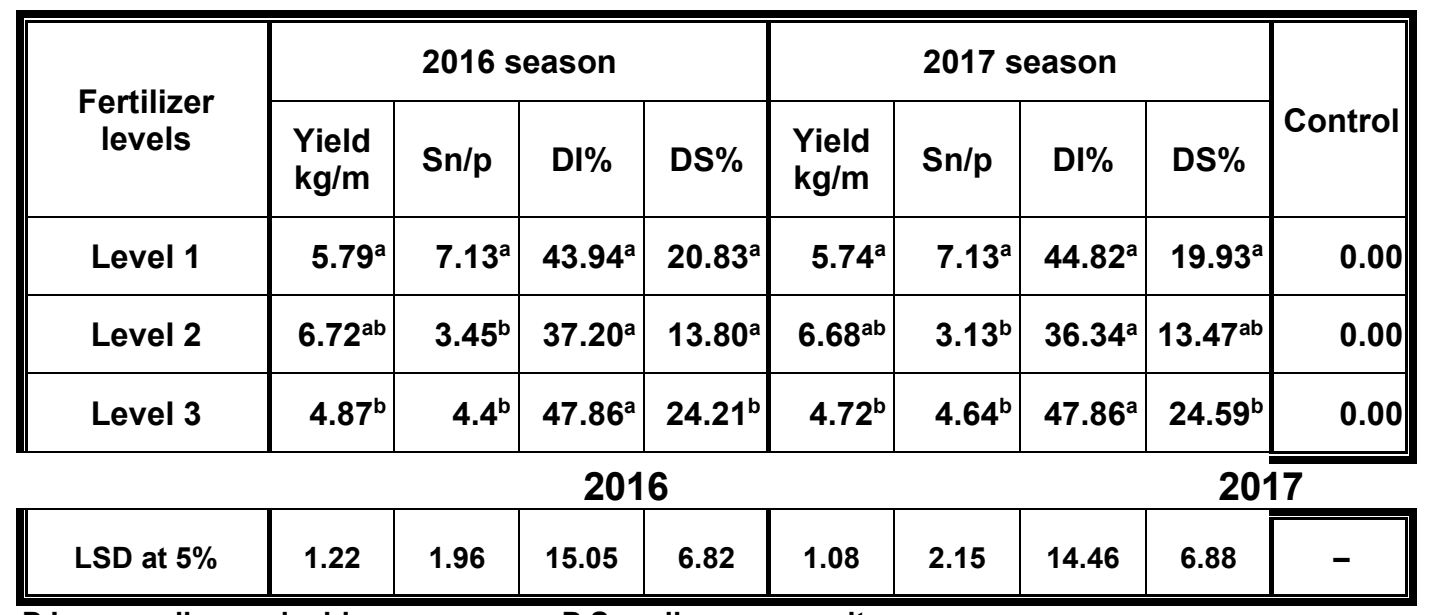

D.I. disease incidence D.S. disease severity

S.N./P. Sclerotia bodies number/plant

Y/M2 Yield/meter2 
White mold disease can be controlled by choosing the best planting date, because it helps to avoid the occurrence of the disease or reduce the severity of infection. Disease amount fluctuated according to transplanting date. In this experiment, data indicate, significant differences in white mold disease severity and disease incidence were observed between the earliest trans planting date $10^{\text {th }}$ March and each one of the other two dates, $20^{\text {th }}$ July and $20^{\text {th }}$ November during two growing seasons. The highest disease severity was obtained with transplanting on $20^{\text {th }}$ November, as well as yield production of pepper differed according to the transplanting date, where the highest yield of pepper were accorded with transplanting on 21th July, similar results were obtained by Zhang, J. X. ; Xue, A. G. (2010), Liang Yue et al., 2013), Mohamed and Asmaa (2015) and AbdElhakam (2017).

\section{REFERENCES}

Abd-Elhakam, A. Sh. (2017). Studies on white mould disease of beans. Ph.D. Thesis, Faculty of Agriculture, Menoufia University, p. 92.

Mohamed, Asmaa and Ahmed, Shebl (2015). Studies on postharvest fungal diseases of some cucurbits. Ph.D. Thesis, Faculty of Agriculture, Menoufia University, p. 144.

Liang, Yue, W. Yajima, M.R. Davis, N.N.V. Kav and S.E. Strelkov (2013). Disruption of a gene encoding a hypothetical secreted protein from Sclerotinia sclerotiorum reduces its virulence on canola (Brassica napus). Canadian Journal of Plant Pathology, 35 (1): 46 - 55.

Zhang, J. X. and A. G. Xue (2010). Biocontrol of sclerotinia stem rot (Sclerotinia sclerotiorum) of soybean using novel Bacillus subtilis strain SB24 under control condition. Plant Pathology. 59(2): 382-391
Ma Yan, Chang ZhiZhou, Zhao JiangTao, Huang HongYing, Ye XiaoMei and Zhang JianYing (2006). Antifungal activity of Penicillium striatisporum strain P.st10 and its inhibition against pepper blight caused by Phytophthora spp. Chinese Journal of Biological Control; 2006. 22(3): 239-243. 14.

M Yusuf, Y. Sally (2004). Effect of treating pepper with benzothiadiazole derivative and non-pathogenic Xanthomonas campestris pathovars on the level of disease caused by Sclerotinia sclerotiorum. Plant Pathology Journal. 3(1): 52-55. 26.

Cother, E. J. (2000). Pahtogenicity of Sclerotinia sclerotiorum to Chrysanthemoides monililifera ssp. Rotundata (Bitoubush), and selected species of the costal flora in eastern Austraia. Biological control, 18: 10-17.

Elad, Y. (2000). Biological controlof foliar pathogens by means of Trichoderma harzianum and potanital modes of action. Crop protection, 19: 709-714.

Vieira, R. F., C. M. F. Pinto and T. J. Paula Junior (2003). Chemigation with benomyl and fluazinam and their fungicidal effects in soil for white mold control on dry beans. Fitoptologia Brasileira, 28: 245-250.

Derbyshire, M., M. Denton-Giles, D. Hegedus, S. Seibarghy, Rollins, J, van, M. F. Seidl, L. Faino, M. Mbengue, 0. Navaud, S. Raffaelo, K. HammondKosack, S. Heard and R. Oliver (2017). The complete genom sequence of the pathogenic fungus Sclerotinia sclerotiorum reveals insights into the genome architecture of broad host range pathogens.Genome Biology and Evolution. 9(3): 935-618.

Babu, B. S., S. R. Pandravada, R.D. Prasoda, V. J. Rao, K. Anit, S. K. Chakrabarty and K. S. Varaprasad (2002). Global sources of pepper genetic resources against arthropods, nematodes and pathogens. Crop protection, 30: 389-400 pp. 
مكافحة مرض العفن الأبيض في الفلفل باتباع بعض العمليات الزراعية

محمد أحمد عوض، السعيد زكى خليفه، محمد عيسى إبراهيم ليله

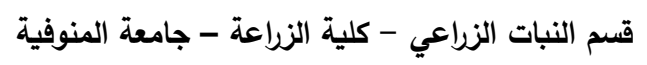

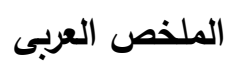

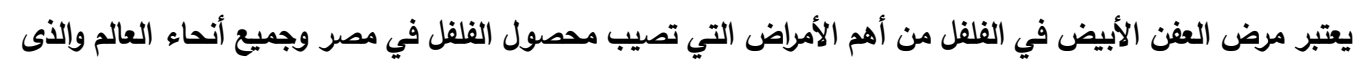

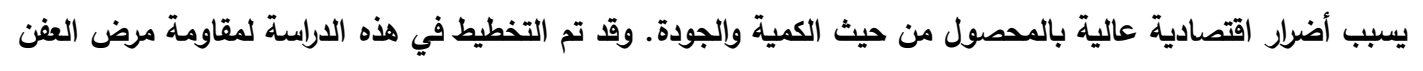

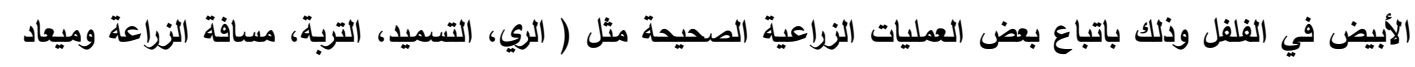

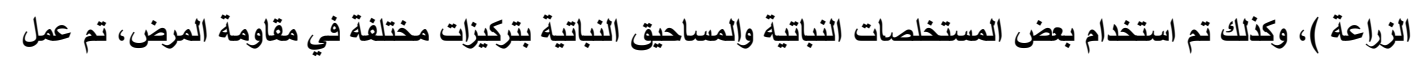

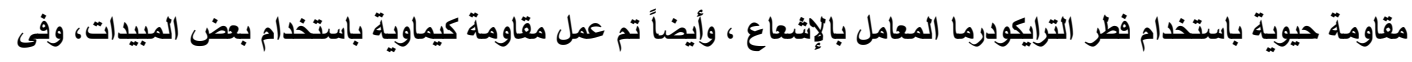
النهاية تم عمل مقاومة متكاملة عن طريق تطبيق أفضل المعاملات الفردية السابقة.
}

السادة المحكين

أ.د / جهاد محمد دسوقى الهباء كلية الزراعة - مشتهر - بنها

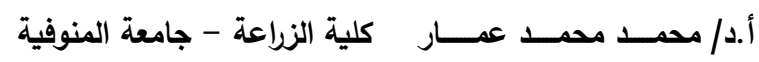

